\title{
The implementation of Small Private Online Courses (SPOC) as a new approach to education
}

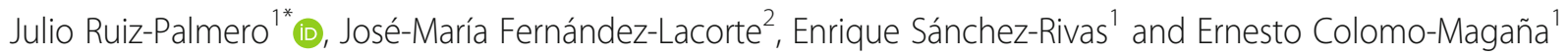

\footnotetext{
*Correspondence: julio@uma.es 'University of Málaga, Málaga, Spain Full list of author information is available at the end of the article
}

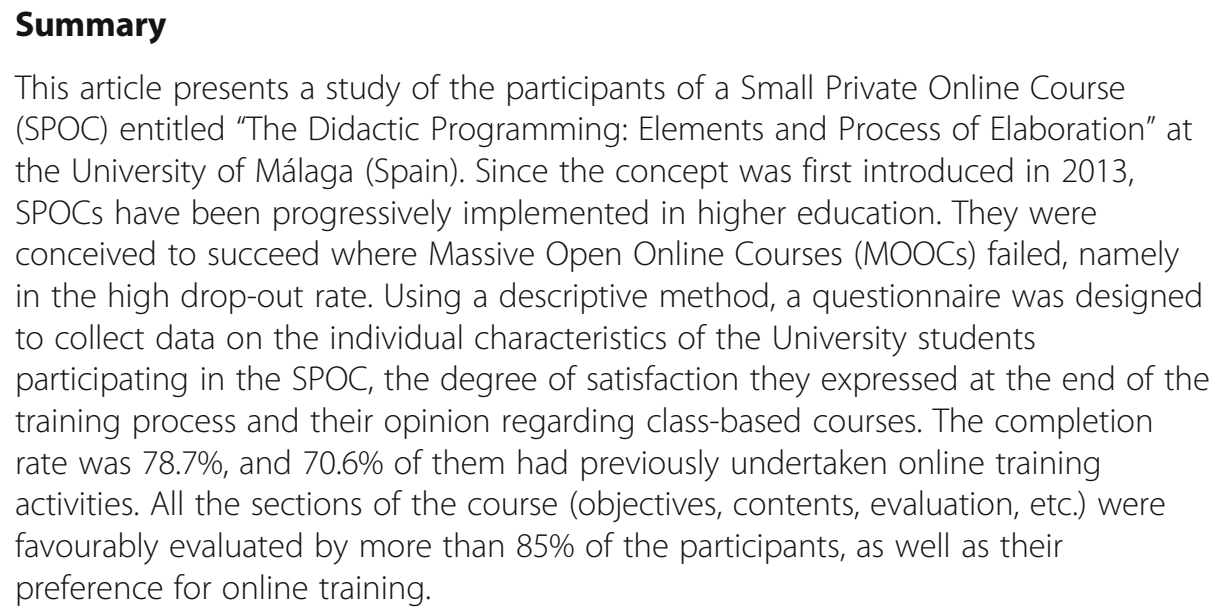

This article presents a study of the participants of a Small Private Online Course (SPOC) entitled "The Didactic Programming: Elements and Process of Elaboration" at the University of Málaga (Spain). Since the concept was first introduced in 2013, SPOCs have been progressively implemented in higher education. They were conceived to succeed where Massive Open Online Courses (MOOCs) failed, namely in the high drop-out rate. Using a descriptive method, a questionnaire was designed to collect data on the individual characteristics of the University students participating in the SPOC, the degree of satisfaction they expressed at the end of the training process and their opinion regarding class-based courses. The completion rate was $78.7 \%$, and $70.6 \%$ of them had previously undertaken online training activities. All the sections of the course (objectives, contents, evaluation, etc.) were favourably evaluated by more than $85 \%$ of the participants, as well as their preference for online training.

Keywords: SPOC, Innovation, Higher education, Pedagogical discourse

\section{Introduction}

For a long time, technological advances have meant a major challenge and transformation for universities, which are trying to take advantage of the advances offered by technology.

However, the pace at which these advances have been introduced into class-based teaching has never been in line with the evolution of technology, not least because teachers are not fully convinced that they will improve students' learning achievements or their school performance (Freitas \& Paredes, 2018; Rodríguez, Olaskoaga, \& Marúm, 2017).

Despite this, distance education in general (900\% worldwide since 2000 - Muñiz, 2017) has not stopped growing. The increase is similar in the university environment: according to data from the Spanish Ministry of Education and Vocational Training (MEFP), in 2018 69.2\% of new university students took class-based courses, while $30.8 \%$ opted for distance education.

This is where we can find MOOCs, which are basically free online courses that combine lectures in audio or video format (of no more than 10 to $15 \mathrm{~min}$ ), text documents

(c) The Author(s). 2020 Open Access This article is licensed under a Creative Commons Attribution 4.0 International License, which permits use, sharing, adaptation, distribution and reproduction in any medium or format, as long as you give appropriate credit to the original author(s) and the source, provide a link to the Creative Commons licence, and indicate if changes were made. The images or other third party material in this article are included in the article's Creative Commons licence, unless indicated otherwise in a credit line to the material. If material is not included in the article's Creative Commons licence and your intended use is not permitted by statutory regulation or exceeds the permitted use, you will need to obtain permission directly from the copyright holder. To view a copy of this licence, visit http://creativecommons.org/licenses/by/4.0/. 
and tasks automatically graded by the learning management system (LMS) in which it is hosted or by other students enrolled in the same course. There is no need for a specific profile nor is there a limit to the number of students that can enrol in a given course, therefore the course teachers' tutorial work is minimal, and this responsibility is left to fellow students through forums (Ruiz-Palmero, López-Álvarez, Sánchez-Rivas, \& Sánchez-Rodríguez, 2019). Thus, the massification and heterogeneity of the people enrolled are basic characteristics of MOOCs (Garcia, Fidalgo, \& Sein, 2017).

Since MOOCs were first created, universities have been taking part as institutions of higher education. Nowadays around 1000 universities offer more than 14,000 MOOCs on different platforms (List of 943 Universities offering MOOCs/free online courses, 2019). They are also offering Small Private Online Courses (SPOCs), a term first coined by Professor Armando Fox at the University of Berkeley in Fox, 2013 which implies an adaptation of MOOCs to suit the specific needs of an educational body, diversification that obeys educational criteria tending to personalize learning (Escudero-Nahón, 2020). While MOOCs help update general knowledge and are directed to large groups, SPOCs allow the development of educational projects for specific communities, adjusting the contents to their needs. MacVie (cited in Aguayo \& Bravo, 2017) difference between: COOC (corporative open on-line courses), courses designed for companies; SOOC (small open online courses), low-audience courses due to the extreme specialization of the subject and NOOC (nano open online courses), characterized by requiring less than $20 \mathrm{~h}$ of dedication.

\section{Theoretical framework}

SPOCs were created to succeed where MOOCs failed, namely in the high drop-out rate (Eriksson, Adawi, \& Stöhr, 2017; Veletsianos \& Shepherdson, 2016). They are, therefore, non-open courses with a smaller number of participants who have to meet specific requirements (Aguayo \& Bravo, 2017; Álvarez-Gil, Montes-Sancho, \& Tachizawa, 2017). As a result, the relationship with tutors is closer than in MOOCs.

Sometimes they have been developed in the university environment, by applying the teaching resources used in MOOCs, as a training course for the teaching staff, (Santamaría, 2014) or as a supplement to degree courses (López, 2016; Wang, Wang, Wen, Wang, \& Tao, 2016; Zhang et al., 2019; Zheng, Chu, Wu, \& Gou, 2018), strengthening blended learning teaching so that students can adjust their learning pace to the contents and explanations of the lessons (Lou, Zheng, \& Jiang, 2016).

According to Aguayo and Bravo (2017) the methodology used in the SPOCs, "has its central axis in the use of short videos (and video-simulation) for the transmission of knowledge and autonomous activities with automatic correction tests and in some cases of peer-to-peer activities, with the possibility of representing highly complex phenomena" (p.134), which are ideal for transmitting concepts at a higher education level based on adaptive learning and have a series of characteristics that differentiate them from traditional online education courses.

However, incorporating online teaching is not easy (Liyanagunawardena, Adams, \& Williams, 2013), and studies are needed to analyse the benefits of SPOCs in order to create appropriate learning environments in which to encourage real, consensual and lasting innovation, which can shape the way in which students and teachers interact, 
encourage more participation and active roles among the former and more support and guidance among the latter.

As of 2013, MOOCs started to receive attention from the scientific community (Karsenti, 2013). Since then, the number of researches on this training format has been increasing, and nowadays it is a major part of scientific literature (for example, a search in the Journal Citation Report -JCR- on MOOC or "massive open online course" gives 1751 results). However, there hasn't been that much interest in SPOCs (a search in JCR from 2013 to 2019 on SPOC or "small private online course" gives 138 results). Terms such as COOC, SOOC or NOOC have not been sought because our course does not adjust to their characteristics.

Analysing their evolution, one could say that, after an initial stage when their advantages and disadvantages were identified (Fernández-Ferrer, 2019), MOOCs have become consolidated as a training option. For SPOCs to achieve a similar level of consolidation, more research should be carried out in areas such as the perception that students have of them and their quality, the profile of the participants, the motivations that lead them to study, etc.

Specifically, this paper addresses the following research questions:

- Which is the opinion of the participants in the first edition of SPOCs at the University of Málaga (Spain)?

- Do they prefer this training format as opposed to others class-based options?

\section{Methodology}

\section{Context and participants}

At the end of May 2019, the first call was published for the development and delivery of SPOCs to the UMA's education community (First Comprehensive Teaching Plan), which was going to offer cross-disciplinary skills or additional training to complement the University's official degrees.

Two courses were selected in this call, one of them entitled "La programación didáctica: elementos y proceso de elaboración" (The Didactic Programme: Elements and Elaboration Process), which was held from October to December 2019.

It was advertised throughout the entire university community (students, teaching and research staff -TRS-, administration and services staff -ASS-) through mailing lists and social networks. Applications were accepted on a first-come, first-served basis, up to a maximum of 160 participants, as four tutors delivered the course (40 participants per tutor). It was free for the participants, apart from the university certificate for the participants who, once the training was completed with a positive result, chose to apply for it.

The course was divided into three blocks:

- Policy: in education related to didactic programming and syllabus development.

- Basic elements of didactic programmes: competences, objectives, contents, methodology.

- Evaluation: general aspects, criteria, how and when to evaluate and current regulations. 
It was developed in 6 weeks and was equivalent to three ECTS (European Credit Transfer and Accumulation System) credits. The evaluation in each module was carried out using a self-corrected questionnaire with the UMA's LMS. In addition, one of the requirements was the delivery of a task to be marked, which had to be positively evaluated by the tutors. The communication channels were the LMS's internal messaging systems and forums.

The participants of this survey were the people who took part and finished the SPOC. A non-probabilistic (accidental) sampling was therefore carried out.

\section{Instrument}

For the collection of data, an ad hoc questionnaire was used, which was included in the last section of the course within the LMS and completed on a voluntary basis.

Its layout was carried out in different phases:

- Questions and answers were defined; they were tested by a pilot sample made of students, teachers and administrative and service personnel, all volunteers, who initially were not going to take part; finally, some of the sections were modified, which made it possible to correct elements related to the understandability of the items and the response options.

- The final product was submitted to a panel of experts (Delphi method) (Reguant \& Torrado, 2016), and the tool was then completed.

Once the validation process was completed, the questionnaire was computerised through LimeSurvey, that guarantees the anonymity of the responses; the program provides information about the people who have answered the questionnaire (in order to be able to send reminders) but not the specific answers. Different types of questions were developed: multiple choice, closed and open questions. In addition to the questions on the course evaluation and comparison with the classroom mode (for which a 5-point Likert scale was used), data was also collected from students on gender, age, relationship with the University and previous experience in online courses.

When the students finished the course, the tutors directed them to the link where they could take the survey. The students who sent the questionnaire with their answers formed the final sample of the study (102 in total).

The reliability of the questionnaire was analysed with the Cronbach's Alpha coefficient applied to the course assessment questions and to the comparison of the course with the class-based mode. The score obtained was 0.936 , which makes it possible to establish the instrument validity.

The data obtained was exported from LimeSurvey and analysed with the SPSS programme.

\section{Results}

Instructions on how to access the course location on the LMS were sent to the 160 admitted participants, out of which: 
- 110 finished the course.

- 7 sent at least some tasks, although they did not complete the course.

- 28 did nothing (not even the questionnaire or any tasks).

- 102 filled in the questionnaire at the end of the course.

- 93 requested the certification.

The completion rate of the course is $68.7 \%$ if we consider all the admitted participants but rises to $75.9 \%$ if we count those who accessed the LMS and $94 \%$ with those who did something in it.

With regard to the gender variable, $65.7 \%$ of the course participants were women and $34.3 \%$ were men, most of whom were students $(57.8 \%)$ (Table 1 ).

The age average is around 30.46 years old, with a typical deviation of 9.1. The mode is 19 years $(n=7)$. Table 2 shows them grouped by age ranges with different values as the majority of course participants are students who are younger than the TRS and the ASS (Fig. 1).

As for their previous experience in online training activities, $70.6 \%$ had previously carried out this type of activities, there is no information on the connections with the university $\left(\chi^{2}(5, N=102)=8.581, p>.005\right)$ (Table 3$)$, although there is an age range $\left(\chi^{2}(5, N=102)=20.680, p<.005\right)$ (Table 4$)$, as both the youngest and the oldest groups are proportionally those who have taken fewer online courses.

For the course evaluation and its comparison with a class-based course, a Likert scale with five values was used: strongly disagree (1), disagree (2), neither agree nor disagree (neutral) (3), agree (4), strongly agree (5).

The sections of the course to be evaluated were the following: the guide used to advertise it, the objectives, contents, duration, evaluation, communication with the tutors and the benefits of carrying out the course (Table 5).

According to $97 \%$ of the participants (agree or fully agree), the course guide clearly explained the course objectives. $95.1 \%$ say that they meet their training needs and $99 \%$ that they are realistic and achievable.

With regard to the contents, they indicated that they are current $(95.1 \%)$, clear and understandable (96.1\%), in line with their training needs (86.3\%), interesting (88.2\%), sufficient and appropriate for the completion of the course (94.1\%).

On whether they have had sufficient time to do so, $96.1 \%$ agree or totally agree, the figure dropped to $92.2 \%$ on whether the duration is proportionate to the contents.

The evaluation was consistent with the objectives and contents of the course for 92.2\% of the respondents (agree or totally agree), evaluation criteria were clear for $90.2 \%$ and the questionnaires adequate for $94.2 \%$.

Table 1 Gender and connections with the University

\begin{tabular}{lllll}
\hline & \multicolumn{2}{l}{ Gender and connections with the University } & Total \\
\cline { 2 - 4 } & Students & TRS & ASS & \\
\hline Gender & & 16 & 1 & 67 \\
Female & 50 & 21 & 5 & 35 \\
Male & 9 & 37 & 6 & 102 \\
Total & 59 & &
\end{tabular}


Table 2 Age range (years)

\begin{tabular}{llll}
\hline & Frequency & Percentage & Accumulated percentage \\
\hline$<=20$ & 14 & 13.7 & 13.7 \\
$21-25$ & 24 & 23.5 & 37.3 \\
$26-30$ & 16 & 15.7 & 52.9 \\
$31-40$ & 34 & 33.3 & 86.3 \\
$41-50$ & 9 & 8.8 & 95.1 \\
$>50$ & 5 & 4.9 & 100.0 \\
Total & 102 & 100.0 & \\
\hline
\end{tabular}

90.2\% agree or totally agree that communication with the tutors was easy and $92.2 \%$ agree that their response to the questions was fast and clear

$87.2 \%$ stated that they updated the methodology used in their work, $85.3 \%$ have a better idea on how to carry it out, $88.2 \%$ that the course fulfilled their expectations and 91.2\% would recommend it to other people

In none of the items on Table 5 there is a relation with the "connections with the University" variable nor with the "gender" variable.

Table 6 shows the questionnaire items regarding the participants' opinion about online versus class-based training.

There is a broad consensus among the participants (agree or totally agree) that the online format is better suited to their schedule $(95.1 \%)$ and that it helps reconcile work and family life (96.1\%).

Regarding their preference for online rather than classroom training, 85.3\% (agree or strongly agree) would take an online course rather than a classroom one, $34.3 \%$ say that online training is better than classroom training (compared to $10.8 \%$ who disagree).

The items in Table 6 only show a relationship between the gender variable and the preference to take an online course rather than a classroom course $\left(\chi^{2}(3, N=102)=\right.$

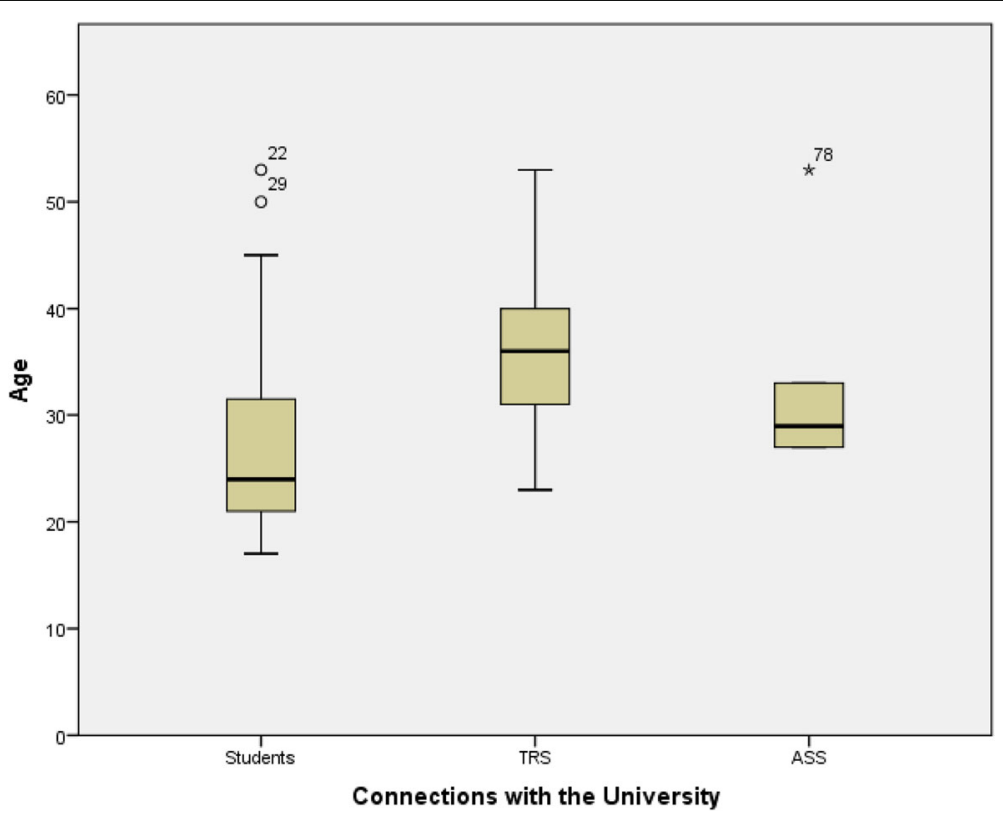

Fig. 1 Age and connections with the University 
Table 3 Have you ever taken an online course before?

\begin{tabular}{lllll}
\hline & Students & TRS & ASS & Total \\
\hline Yes & 35 & 32 & 5 & 72 \\
No & 24 & 5 & 1 & 30 \\
Total & 59 & 37 & 6 & 102 \\
\hline
\end{tabular}

$11.884, p<.005)$ with more women than men showing a preference for online training $\left(\chi^{2}(4, N=102)=10.015, p<.005\right)$.

There is no relationship with the "connections with the University" variable.

Finally, we have included two open questions regarding the strengths and weaknesses of the course. One of the strongest points is the online format, which adapts to the needs of each participant:

"The best thing about this type of course is its convenience, as it has no fixed schedule and it is quite flexible. Moreover, it is fairly quick, and it does not take up too much time."

- "It's easy to organize my time and combine it with my family life."

The tutors' work and the contents are also highlighted:

- "Even if it was an online course, the attention of the teachers has been much greater than in classroom subjects I have attended."

- "It was all very clear and well explained. The teachers have been very attentive, answering questions fast and correcting tasks quickly. Moreover, they gave us feedback on the task. To be honest, I have been very surprised by the efficiency of the course. The videos were short, but clear and concise."

- "It covers many topics related to teaching and its organization that I was unaware of, as there are currently few courses that deal with this subject."

As for the weak points, interesting suggestions were made that will be taken into account in a future edition of SPOC: on the tasks, time of completion of the course, depth of contents, etc.:

Table 4 Have you ever taken an online course before?

\begin{tabular}{llllllll}
\hline & \multicolumn{2}{l}{ Age range (years) } & Total \\
\cline { 2 - 8 } & $<=20$ & $21-25$ & $26-30$ & $31-40$ & $41-50$ & $>50$ & \\
\hline Yes & 4 & 17 & 14 & 26 & 9 & 2 & 72 \\
No & 10 & 7 & 2 & 8 & 0 & 3 & 30 \\
Total & 14 & 24 & 16 & 34 & 9 & 5 & 102 \\
\hline
\end{tabular}


Table 5 Course sections

\begin{tabular}{|c|c|c|c|c|c|}
\hline & 1 & 2 & 3 & 4 & 5 \\
\hline The course guidelines clearly state the objectives & & & 3 & 49 & 50 \\
\hline The objectives are in line with my training needs & 1 & & 16 & 43 & 42 \\
\hline The objectives are realistic and achievable & & & 1 & 33 & 68 \\
\hline The contents of the course are current & & 2 & 3 & 23 & 74 \\
\hline The contents are clear and easily understood & & 1 & 3 & 33 & 65 \\
\hline The contents are in line with my training needs & 1 & 4 & 9 & 41 & 47 \\
\hline The contents are interesting & & 1 & 11 & 44 & 46 \\
\hline The contents have been sufficient and adequate for the completion of the course & 1 & 1 & 4 & 38 & 58 \\
\hline I had enough time to complete the tasks & & & 4 & 19 & 79 \\
\hline The duration of the course is proportionate to its contents & & 3 & 4 & 31 & 64 \\
\hline The evaluation has been consistent with the objectives and contents & & 1 & 7 & 23 & 71 \\
\hline The course evaluation criteria are clear & 1 & 4 & 5 & 24 & 68 \\
\hline The questionnaires at the end of each section are adequate & 2 & & 4 & 24 & 72 \\
\hline Communication with the tutors has been easy & & & 10 & 15 & 77 \\
\hline Doubts and queries have been answered quickly and clearly & & & 8 & 17 & 77 \\
\hline This course has enabled me to update the methodologies I use in my daily work & 1 & 3 & 19 & 37 & 42 \\
\hline With the training I received I now know more and carry out my work better & 1 & 5 & 9 & 39 & 48 \\
\hline Overall, the course met my expectations & 1 & 2 & 9 & 39 & 51 \\
\hline I would recommend other people to take the course in future editions & 1 & 1 & 7 & 24 & 69 \\
\hline
\end{tabular}

- "Excessive length of the course in relation to its contents."

- "Perhaps it would be useful if the participants carried out a greater number of tasks or developed a teaching guide."

- "I think that the methodologies described should have been dealt with more thoroughly."

\section{Discussion and conclusions}

The results obtained in this research are to be studied in the context of a SPOC developed in the first edition of this type of course in a specific university. Considering this limitation, the conclusions reached allow us to broaden the existing knowledge of the profile and preferences of the participants in our SPOC by making a comparison with other training modalities.

Firstly, SPOCs have a high completion rate (75.9\%), significantly higher than that obtained by MOOCs, where the drop-out rate is over 60\%. (Chuang \& Ho, 2016; Monllaó

Table 6 Online - class-based format

\begin{tabular}{llllll}
\hline & 1 & 2 & 3 & 4 & 5 \\
\hline As it is online it fits in with my schedule & & 5 & 12 & 85 \\
As it is online, I can combine it with my work and family life & & 4 & 15 & 83 \\
I would take a course with the same methodology instead of a class-based one & 5 & 10 & 29 & 58 \\
I believe that distance learning is of better quality than the class-based option & 2 & 9 & 56 & 20 & 15 \\
\hline
\end{tabular}


Olivé, Huynh, Reynolds, Dougiamas, \& Wiese, 2019; Oliver, Hernández-Leo, \& Albó, 2015; Ruiz-Palmero et al., 2019). This fact has already been pointed out in other research (Santamaría, 2014). We agree with Gardair et al. (2016) in attributing the high completion rate to the fact that SPOCs are designed for a specific audience and therefore have a greater capacity to adapt to the interests and training needs of the participants.

When delving into the profile of the participants, we found that a high percentage (70.6\%) had previously taken online courses. We believe that people who enrol in these type of activities consider online training as a one of their learning resources (Martínez \& Fernández, 2018). We could define them as advanced participants, who have sufficient comparative criteria to be able to make informed judgements on the quality of the course. This is why the result of the teaching process evaluation is important, as the majority (more than 90\%) stated that the course was in line with the needs of the participants. They also evaluate the objectives of the course as realistic and achievable, conditions that we take as an indicator of its quality (del Moral \& Villalustre, 2004).

Considering the participants' personal variables, we found that it breaks the gender gap that other researches have identified in MOOCs (Almjeld, 2019; Castaño, Maiz, \& Garay, 2015; Sánchez-Rivas, Álvarez, Vega, \& Ruiz-Palmero, 2018), where there are more men taking part than women. However, in the SPOC we have analysed, this trend is reversed, with $65.7 \%$ of women versus $34.3 \%$ of men, data that corresponds to a greater female presence at the University of Malaga, in which $58.4 \%$ of people are women and $41.6 \%$ men). Obviously, it could be due to accidental sampling, but we consider it to be an issue worthy of analysis in future studies.

The gender perspective and online training is undoubtedly an open line of research, which can provide valuable knowledge in favour of equality between men and women. New technology-based training courses, and especially MOOCs, still have a lot of room for improvement in this respect.

Considering MOOCs as instruments that promote democratic participation in a horizontal manner and constitute a community of equal users, with no hierarchies, is not realistic (...) Gender sets distances that cannot be ignored if we seek to develop real equality, and MOOCs must take this into consideration. (Herrada, Montes, \& Ballarín, 2018, p. 149).

Another aspect to be highlighted is transfer, i.e. the degree to which the knowledge and skills acquired through the training is then used by the trainees in their work (Pereda, Berrocal, \& Alonso, 2014). In this respect, we found that a high percentage of participants $(87.2 \%)$ claim to have updated and improved the methodologies they use in their work.

As Aneas Novo (2018) mentioned, satisfaction is an essential aspect of the transfer process. We were able to determine that the analysed SPOC received an excellent evaluation in terms of the satisfaction of the participants, who assure that it has had a positive impact on their professional life (Vaysse et al., 2018), that it has met their expectations (Santamaría, 2014) and that they recommend it to other people.

The conclusions obtained in terms of satisfaction are consistent with the preferences expressed by the participants, who find greater advantages in training through the 
SPOC than in other classroom training. The reason they give is the flexible timetable offered by online courses, which makes it possible to reconcile family life and training obligations.

Finally, a future edition of the SPOC will be used to modify the sections that can be improved: depth of content, some technical issues and increased interactivity.

As future lines of action we would like to point out the need to continue deepening the knowledge of SPOCs as an alternative training modality to MOOCs. Because of the experience in the design, development and study of this course we would like to develop it further, integrating the pooled analysis with the didactic elements of flipped classrooms, which will increase the adaptation to the students' circumstances (Wang et al., 2016).

Based on the conviction that students' needs and interests must take centre stage in university teaching, we consider it worthwhile to carry out studies on the impact of the SPOC on teaching components such as: the use of time dedicated to training, the channels of student participation, their motivation or the academic performance they achieve. Previous research on this topic with other CHANGE methodologies has shown excellent results in the comparison with traditional university teaching processes (Aneas, Sánchez-Rodríguez, \& Sánchez-Rivas, 2019; Sánchez-Rivas, Ruiz-Palmero, \& Sánchez-Rodríguez, 2019; Sánchez-Rivas, Sánchez-Rodríguez, \& Ruiz-Palmero, 2019).

At the same time, we should not forget the gender perspective in terms of scientific knowledge. Information and communication technologies are associated with a digital gender gap (Cabero \& Ruiz-Palmero, 2018). Hence the pressing need to know the impact SPOCs have in this area and how we can change its design to improve gender inclusion.

\section{Abbreviations}

ASS: Administration and services staff; JCR: Journal citation report; LMS: Learning management system; MOOC: Massive open online courses; SPOC: Small private online course; TRS: Teaching and research staff

\section{Acknowledgments}

Not applicable.

\section{Authors' contributions}

All authors have read and agree to the published version of the manuscript. Conceptualization and writing - review and editing, JMFL and JRP; methodology, software, and formal analysis, ESR and JRP; resources and data curation, ESV and ECM. The author(s) read and approved the final manuscript

\section{Funding}

This research was funded by a grant from the University of Malaga (project reference number: 715/2019). First Comprehensive Teaching Plan of the University of Malaga.

\section{Availability of data and materials}

The datasets generated and/or analysed during the current study are not publicly available due confidential issues but are available from the corresponding author on reasonable request.

Competing interests

The authors declare that they have no competing interests.

\section{Author details}

${ }^{1}$ University of Málaga, Málaga, Spain. ²Education and Sports Counseling Málaga, Málaga, Spain.

Received: 12 February 2020 Accepted: 16 April 2020

Published online: 03 August 2020

\section{References}

Aguayo, R., \& Bravo, J. (2017). Implantación de un SPOC en la educación a distancia Para la mejora del proceso de enseñanza-aprendizaje. Revista Tecnología, Ciencia y Educación, 6, 129-142. 
Almjeld, J. (2019). Getting "girly" online: The case for gendering online spaces. In Gender and diversity: Concepts, methodologies, tools, and applications, (pp. 871-889). https://doi.org/10.4018/978-1-5225-6912-1.ch044.

Álvarez-Gil, M. J., Montes-Sancho, M. J., \& Tachizawa, E. M. (2017). A first approximation to the SPOCs-FC in the context of the supply chain management. WPOM-Working Papers on Operations Management, 8, 151-163. https://doi.org/10.4995/ wpom.v8i0.7198.

Aneas, C., Sánchez-Rodríguez, J., \& Sánchez-Rivas, E. (2019). Valoración de la formación del profesorado: Comparativa entre autoformación y formación presencial. Gestión y Análisis de Políticas Públicas (GAPP), 1(21), 94-108. https://doi.org/10. 24965/gapp.v0i21.10569.

Aneas Novo, C. (2018). Valoración de la transferencia en las modalidades de autoformación y formación presencial. Innoeduca: international journal of technology and educational innovation, 4(2), 193-203. https://doi.org/10.24310/ innoeduca.2018.v4i2.5303.

Cabero, J., \& Ruiz-Palmero, J. (2018). Las Tecnologías de la Información y Comunicación Para la inclusión: Reformulando la brecha digital. IJERI: International journal of Educational Research and Innovation, 9, 16-30.

Castaño, C., Maiz, I., \& Garay, U. (2015). Percepción de los participantes sobre el aprendizaje en un MOOC. RIED. Revista Iberoamericana de Educación a Distancia, 18(2), 197-221. https://doi.org/10.5944/ried.18.2.13444.

Chuang, I., \& Ho, A. (2016). HarvardX and MITX: Four years of open online courses https://ssrn.com/abstract=2889436.

del Moral, M. E., \& Villalustre, L. (2004). Indicadores de calidad en la docencia virtual: Adaptación de los entornos a la diversidad cognitiva de los estudiantes. Aula abierta, 84, 155-172.

Eriksson, T., Adawi, T., \& Stöhr, C. (2017). «time is the bottleneck»: A qualitative study exploring why learners drop out of MOOCs. Journal of Computing in Higher Education, 29(1), 133-146. https://doi.org/10.1007/s12528-016-9127-8.

Escudero-Nahón, A. (2020). Análisis crítico al término "masivo" en los MOOC: Una Cartografía conceptual. EDMETIC, 9(1), 188-212.

Fernández-Ferrer, M. (2019). Revisión crítica de los MOOC: Pistas Para su futuro en el Marco de la educación en línea. REDU. Revista de Docencia Universitaria, 17(1), 73-88. https://doi.org/10.4995/redu.2019.11275.

Fox, A. (2013). From MOOCs to SPOCs. Communications of the ACM, 56(12), 38-40. https://doi.org/10.1145/2535918.

Freitas, A., \& Paredes, J. (2018). Understanding the faculty perspectives influencing their innovative practices in MOOCs/ SPOCs: A case study. International Journal of Educational Technology in Higher Education, 15(1), 5. https://doi.org/10.1186/ s41239-017-0086-6.

Garcia, F. J., Fidalgo, A., \& Sein, M. L. (2017). Los MOOC: Un análisis desde una perspectiva de la innovación institucional universitaria. La Cuestión Universitaria, 9, 117-135.

Gardair, C., Bousquet, G., Lehmann-Che, J., de Bazelaire, C., de Cremoux, P., Tran Van Nhieu, J., ... Bertheau, P. (2016). Les coulisses d'un massive open online course (MOOC) Sur le diagnostic des cancers. Annales de Pathologie, 36(5), 305-311. https://doi.org/10.1016/j.annpat.2016.08.013.

Herrada, R., Montes, R., \& Ballarín, P. (2018). Rastreando marcas de género en la formación on-line. En Ecologías del aprendizaje. Educación expandida en contextos múltiples (pp. 130-151). Morata.

Karsenti, T. (2013). The MOOC. What the research says. International Journal of Technologies in Higher Education, 10(2), 23-37.

List of 943 Universities offering MOOCs/free online courses. (s. f.). Recuperado 25 de diciembre de 2019, de https://www. classcentral.com/universities

Liyanagunawardena, T., Adams, A. A., \& Williams, S. (2013). MOOCs: A systematic study of the published literature 2008-2012. International Review of Research in Open and Distance Learning, 14(3), 201-227.

López, A. (2016). Integración de los MOOC en la enseñanza universitaria. El caso de los SPOC [Universidad de Pais Vasco]. https://addi.ehu.es/handle/10810/21968.

Lou, J., Zheng, P., \& Jiang, C. (2016). The enlightenment of SPOC on teaching reform of higher education in China_-Based on the perspective of mastery learning theory. Science Journal of Education, 4(2), 95. https://doi.org/10.11648/j.sjedu. 20160402.22.

Martínez, J. B., \& Fernández, E. (2018). Ecologías del Aprendizaje. Morata: Educación Expandida en Contextos Múltiples.

MEFP (2018). Anuario de indicadores universitarios. Año, 2018 http://www.educacionyfp.gob.es/servicios-al-ciudadano/ estadisticas/universitaria/estadisticas/estadistica-indicadores-universitarios/2018-2019.html.

Monllaó Olivé, D., Huynh, D. Q., Reynolds, M., Dougiamas, M., \& Wiese, D. (2019). A supervised learning framework: Using assessment to identify students at risk of dropping out of a MOOC. Journal of Computing in Higher Education. https://doi. org/10.1007/s12528-019-09230-1.

Muñiz, M. (2017). El 'e-learning' gana cada vez más adeptos https://www.esic.edu/saladeprensa/resources/archivosbd/press_ clippings/37f2fc94430a30d7dba690d94d7e1223.pdf.

Oliver, M., Hernández-Leo, D., \& Albó, L. (2015). MOOCs en España. Análisis de la demanda Universitat Pompeu Fabra. http:// repositori.upf.edu/bitstream/handle/10230/25400/MOOCs_2015_Analisidemanda.pdf?sequence=1.

Pereda, S., Berrocal, F., \& Alonso, M. A. (2014). Bases de psicología del trabajo Para gestión de recursos humanos. Síntesis.

Reguant, M., \& Torrado, M. (2016). El método Delphi. REIRE. Revista d'Innovació i Recerca En Educació, 9(2), 87-102. https://doi. org/10.1344/reire2016.9.1916.

Rodríguez, C. E., Olaskoaga, J., \& Marúm, E. (2017). Condiciones Para la incorporación de las TI a actividades académicas en la educación superior: El Caso de Universidad de Guadalajara. Revista argentina de educación superior, 14, 12-36.

Ruiz-Palmero, J., López-Álvarez, D., Sánchez-Rivas, E., \& Sánchez-Rodríguez, J. (2019). An analysis of the profiles and the opinion of students enrolled on XMOOCs at the University of Málaga. Sustainability, 11(24), 1-15. https://doi.org/10.3390/ su11246910.

Sánchez-Rivas, E., Álvarez, D., Vega, E., \& Ruiz-Palmero, J. (2018). ¿Qué sabemos de los estudiantes de los MOOC? Un estudio de Caso what do we know about Mooc students? A case study Fechas · dates. PUBLICACIONES, 48, 197-212. https://doi. org/10.30827/publicaciones.v48i2.8340.

Sánchez-Rivas, E., Ruiz-Palmero, J., \& Sánchez-Rodríguez, J. (2019). Gamification of assessments in the natural sciences subject in primary education. Educational Sciences: Theory \& Practice, 19(1). https://doi.org/10.12738/estp.2019.1.0296.

Sánchez-Rivas, E., Sánchez-Rodríguez, J., \& Ruiz-Palmero, J. (2019). Percepción del alumnado universitario respecto al Modelo pedagógico de clase invertida. Magis, Revista Internacional de Investigación en Educación, 11(23), 151-168. https://doi.org/ 10.11144/Javeriana.m11-23.paur. 
Santamaría, M. (2014). Moocs y Spocs (small private online courses): Sus posibilidades Para la Formación del Profesorado. HAMUT'AY, 1(1), 6-17. https://doi.org/10.21503/hamu.v1i1.568.

Vaysse, C., Chantalat, E., Beyne-Rauzy, O., Morineau, L., Despas, F., Bachaud, J.-M., ... Fize, A.-L. (2018). The impact of a small private online course as a new approach to teaching oncology: Development and evaluation. JMIR Medical Education, 4(1), e6. https://doi.org/10.2196/mededu.9185

Veletsianos, G., \& Shepherdson, P. (2016). A systematic analysis and synthesis of the empirical MOOC literature published in 2013-2015. The International Review of Research in Open and Distributed Learning, 17(2), 198-221. https://doi.org/10.19173/ irrodl.v17i2.2448.

Wang, X.-H., Wang, J.-P., Wen, F.-J., Wang, J., \& Tao, J.-Q. (2016). Exploration and practice of blended teaching model based flipped classroom and SPOC in Higher University. Journal of Education and Practice, 7(10), 99-104.

Zhang, X.-M., Yu, J.-Y., Yang, Y., Feng, C.-P., Lyu, J., \& Xu, S.-L. (2019). A flipped classroom method based on a small private online course in physiology. Advances in Physiology Education, 43(3), 345-349. https://doi.org/10.1152/advan.00143.2018.

Zheng, M., Chu, C.-C., Wu, Y. J., \& Gou, W. (2018). The mapping of on-line learning to flipped classroom: Small private online course. Sustainability, 10(3), 748. https://doi.org/10.3390/su10030748.

\section{Publisher's Note}

Springer Nature remains neutral with regard to jurisdictional claims in published maps and institutional affiliations.

Submit your manuscript to a SpringerOpen ${ }^{\circ}$ journal and benefit from:

- Convenient online submission

- Rigorous peer review

Open access: articles freely available online

- High visibility within the field

- Retaining the copyright to your article

Submit your next manuscript at $>$ springeropen.com 